\title{
BIOTYPICAL VARIABILITY AMONG FOUR POPULATIONS OF RED PALM WEEVIL RHYNCHOPHORUS FERRUGIAEUS FAB/OLIV. FROM DIFFERENT PARTS OF INDIA
}

\author{
C.P. Ramachandran ${ }^{1}$
}

\begin{abstract}
The red palm weevil rhpichophorus ferrugineus $F A B / O L I V$ is a very serious and dreaded pest of coconut, date and other palms. Being an internal feeder the weevil incidence is detected at a very late stage when the tree has succumbed to weevil attack. Hence conventional control operations may not be very effective. The biotypical variability of the four populations collected from different parts of India showed that the populations are genetically different and strainal variability exists between them. Variations in sex ratio and deleterious genetic effect were observed in the crosses and reciprocal crosses. The weevil has a very high fitness due to high production potential and the absence of effective parasites, predators and pathogens. In spite of the high fitness, in endemic areas weevil population tend to remain at certain levels of intensity. This may be due to certain limiting factors.
\end{abstract}

\section{INTRODUCTION}

The importance of misect genetics $\mathrm{m}$ genetical methods of control has been recognized very recently. The use of SIRM against screw worms and its success made the scientists to think seriously in this direction on other aspects of genetical methods of pest control. Davidson (1974) reviewed literature on hybrid sterility in some dipterans species. Hybrid sterility in lepidoptera was studied in Diparopsis species, Beever et al (1973), Heliothis species; Laster (1972) and La chance (1974), Pyralids; Brower (1977) interstrainal and intespecific sterility in Pectinophora gossypiella and P. Scutigera; La chance and Ruud (1979)

Red pahn weevill rhynchophoru sferrugineus $\mathrm{F}$. is the most dreaded pest of the coconut, date and other palms. The pest is present throughout the coconut growing tracts of India. The grubs are destructive and adults are harmless. The female weevil scoops out a hole in the soft tissues of the palm especially in cut and damaged tissues and lays a single egg in it with the ovipositor. The eggs are sealed with a cement-like substance. The eggs hatch in 2 to 3 days and the grubs feed on the tissue and tunnel into the stem. When the growing bud of the palm is affected due to the feeding of the grubs, the palm succumbs to weevil attack and the crown topples down. The external symptoms of weevil attack, viz. jutting out of fibre and oozing out of brown liquid through the exit hole, drooping of leaves, wilting of central shoot etc. are seen only at a very late stage. Being an internal feeder, it is difficult to detect the weevil infestation at an early stage of attack. As the pest infestation is noticed at a later stage, generally it is difficult to save the palm by curative treatment. Hence early detection of pest infestation and alternate methods of pest control becomes important in the management of red palm weevil.

Gonzalez et al (1979) emphasized the m1portance of study of host preference, behaviour, genetic composition, genetic variation etc. in assigning biotypic status to a population. The intensity and extent of damage may vary between population and biotypes. Normally biotypes are studied for sterility or refractoriness. Other than the above, genetical factors like deleterious genes, homozygous lethal, genes that control diapause and sensitivity to temperature, etc. which affect multiplication of the pest can be used to reduce pest population. Since red palm weevil is spread over a larger area under different agroclimatic and ecological conditions the variations can be large. Reported here are the observations on biological parameters of four populations of red palm weevil collected from different parts of India and $\mathrm{F}_{1}$, and $\mathrm{F}_{2}$, generations of their crosses.

\footnotetext{
${ }^{1}$ CPCPI, Regional Station, Kayangulam, Krishnapuram-690533 Kerala, India.
} 


\section{MATERIALS AND METHODS}

Weevils were collected from four places viz. Chawl (Maharashtra), Arsikare (Karnataka), Mettupalayam (Tamil Nadu) and Kayangulam (Kerala). (Fig. 1). The populations were maintained as four colonies in the laboratory. Sugar cane pieces cut between nods and rind removed from one side were provided as egg laying material. The eggs were collected by pealing the sugarcane piece. The eggs were placed on most absorbant paper kept in petri plates and incubated at room temperature ranging between $23^{\circ} \mathrm{C}$ and $34^{\circ} \mathrm{C}$. The newly hatched grubs were transferred to specimen tubes $(7.5 \mathrm{x}$ $2.5 \mathrm{~cm}$ size) containing artificial diet developed by Rahalkar et al. (1978). After two weeks the grubs were transferred singly into 25 to $30 \mathrm{~cm}$ long sugarcane pieces. These pieces were changed every week till pupation. Pupae were collected and kept in plastic containers and were observed for adult emergence. In all the experiments a minimum of 4 pairs of weevils were used and egg collections were continued till a reasonable number of eggs were collected.

The biological parameters observed were egg hatch, incubation period of eggs, larval period, larval mortality, pupal period, pupal mortality, adult emergence, sex ratio of male to female and mortality from egg to adults. The above data were collected from the four populations of F, and F2 of the crosses of Kayangulam x Mettupalayam, Kayangulam x Arsikare, Arsikare x Kayangulam, Chawl x Kayangulam, Kayangulam x Chawl, Arsikare x Mettupalayam, Mettupalayam x Arsikare and Arsikare $x$ Chawl. The $F_{2}$ was raised from making among the $F_{1}$ progeny.

\section{RESULTS AND DISCUSSION}

Data on percentage of hatch, survival at larval and pupal stage and overall survival rate from egg to adults are presented in Table 1. Maximum survival rate from egg to adult of 20.5 percent was in Mettupalayam population and the lowest of 14.3 percent was in Kayangulam population. The sex ratio also varied and highest female ratio of 1.5 was in Kayangulam and the lowest of 0.5 percent $\mathrm{m}$ Chawl. In the F, progeny the survival rate did not show any relation to parental survival rates. The $F_{1}$, of Klm x Met, Klm x Ars, Ars x Met and Met x Ars showed lesser rates of survival than the parents as a whole. Klm $x$ Chawl gave a higher survival rate than the parents. In the $F_{2}$ progeny $\mathrm{Klm} \times \mathrm{Chw}$, Chw $x$ Klm and Ars x Klm the survival rate was higher than in $F_{1}$, and parents. The other $F_{2}$ progeny showed lesser survival rate than the parental population.

A comparison of the survival rates between $F_{1}$ and $F_{2}$ progeny included that there was an overall increase in survival rate in the $F_{2}$ progeny except for progeny of Ars and Chw. The sex ratio also showed marked difference among the populations $F_{1}$ and $F_{2}$. In crosses were Kayangulam females were used an increase in female ratio was observed.

The data on survival at various stages of development of populations and $F_{1}$ and $F_{2}$ of the different crosses were subjected to chisquare test to test for their independence (Table 2). The four populations examined were more or less similar in survival at the larval and pupal period. In the case of egg hatch the populations showed significant difference. The $F_{1}$ generation of the different crosses showed significant difference in egg hatch and survival at larval stage while in $F_{2}$ only larval survival rate showed significant difference. When the data was analyzed for parent populations, $F_{1}$ and $F_{2}$ together significant difference was observed in egg hatch and survival at larval and pupal stage.

The larval and pupal period for the parent populations as well as for $F_{1}$ and $F_{2}$ generations were subjected to analysis of variance and results are presented mi Table 3 and 4 . The larval period for the population ranged between 48.4 to 55.8 days and did not differ significantly. In the case of pupae it was between 14.4 to 19.3 and varied significantly. The larval period for the $F_{1}$ progeny ranged between 42.3 and 59.2 days and pupae 14.9 to 21.2 days. Larval and pupal period of $F_{1}$ varied significantly. In the case of $F_{2}$ the lowest larval period was 39.9 days and highest was 61.6 days while in pupae it ranged between 11.4 to 21.1 days. The data on larval and pupal period for $\mathrm{F}_{2}$ generation varied significantly. 
The four populations were more or less similar in morphological and other characters. When the populations were crossed the $\mathrm{F}_{1}$ and $\mathrm{F}_{2}$ progeny showed variations in the different characters tested. Some of the crosses and reciprocal crosses showed variations. The survival rates mi the $F_{1}$ and $\mathrm{F}_{2}$ of $\mathrm{Klm} \times$ Ars (Fig. II) were 12.2 and 12.1 while in the reciprocal cross it was 24.3 and 23.9 percent. The $\mathrm{F}_{1}$ of $\mathrm{Klm} \times \mathrm{Chw}$ and its reciprocal cross gave 21.7 and 18.6 percent survival (Fig. II) while in the $F_{2}$ the survival were 33.9 and 28.9 percent (Fig. II). The $F_{1}$ of Ars $x$ Met and its reciprocal cross the survival rate was 6.7 and 6.5 percent respectively while in $F_{2}$ it was 10 and 12.6 percent. The populations tested showed difference in sex ratio and the same was reflected in the $F_{1}$ and $\mathrm{F}_{2}$ crosses (Fig. III). The difference mi sex ratio observed in the populations and variations in $\mathrm{F}_{1}$ and $\mathrm{F}_{2}$ progeny may be due to defects in the genetic make up of the populations tested. The variations observed mi the pooled data for the population $F_{1}$ and $F_{2}$ generations of the different crosses and the varied reaction in the reciprocal crosses indicate that genetical differences exist between the populations tested and can be considered as due to occurrence of different biotypes.

In this context it may be worthwhile to examine the possible factors that regulate weevil attack in field. The insect has a very high fitness due to a high fecundity rate, a favourable male to female ratio, absence of known effective parasites, predators or pathogens with abundant food supply. But in spite of all factors in its favor the insect has never assume such devastating proportions to totally wipe out the coconut industry. Even in endemic areas of pest infestation the pest damage has been reported to be kept at certain level of intensity. The possible factors that limit the weevil population in field may be the non-availability of suitable egg laying sites and the complete utilization of the available sites. Available information suggest that the pest is incapable of laying eggs on surfaces other than cut and injured portions, decayed areas due to bud rot and leaf rot and damaged regions due to Oryctes attack, etc. In view of the above observation the pest could be controlled effectively by a realistic and result oriented control programme. In view of the above, it is suggested that in formulating control operations stress should be given to sanitary measures, detection and curative treatment. In this case of pheromone trapping, it is suggested that the males captured in the traps may be re-released to reduce the possibility of development of non-attraction to pheromone in the population. It has been reported that $\mathrm{R}$ ferrugineus and $\mathrm{R}$. cruentatus mate in laboratory. The study of sterility in these populations and its use in population control may be tried.

\section{ACKNOWLEDGMENT}

I am highly grateful to Dr. M.K. Nair, Director, CPCRI, Kasaragod, Dr. P.K. Koshy, Dr. E.V.V. Bhaskara Rao, Dr. K.K.N. Nambiar and Dr. C.P. Radharishnan Nair, CPCRI for their critical comments and suggestions. I am highly indebted to Mr. Jacob Mathew for the statistical analysis of the data. My thanks are also due to Sri Keshavan Nampoothiri and my colleagues who had rendered help at various stages of the research prograrnme. 


\section{REFERENCES}

Beever, P.S., Campion, G.G., Moor House, J.E., Nesbitt, B.F. 1973. Cross attractancy and cross mating between the red bool-worms Diparopsis castanea Hmps and Sudan bollworms Diparopsis watersi (Roths) (Lep: Noctuidae). Bull. Ent. Res. 62 (3): 439-442

Brower, J.H. 1977. Interspecific matings between stored product pyralidae (Phycitinae) Journal of the Georgia Entomological Society 12(3): 215 -220

Davidson, G. 1974. Genetic control of insect pests. Academic Press, New York. 158 pp.

Gonzales, D., Gordh, G., Thornson, S.N. and Alder, J. 1979. Biotype discrimination and its importance to biological control. Working papers. A Rockefeller Foundation Conference March 31 to April 5, 1978. Ma orie, A., Hay and John, J. Mc Kelvey Jr. Edn. pp. 129-136.

La chance, L.E. and Ruud, R.L. 1979. Interstrain and interspecific crosses between Pectinophora gossypiella and P. scutigera. J. Eco. Ent. 72 (4): 618-620.

Laster, M.L. 1972. Interspecific hybridisation of Heliothis virescens and H. Subfluxa. Environ. Entomol. 1: 682-7.

Proshold, F.I. and La chance L.E. 1974. Analysis of sterility in hybrids from interspecific crosses between Heliothis virescens and H. Subfluxa. Ann. Entomol. Soc. Am. 67: 445-49.

Rahalkar, G.W., Tanihankar, Al and Santharam, K. 1978. An artificial diet for rearing red palm weevil. Rhynchophorus ferrugineus Oliv. J. Plant. Crop 3 (2): 65-67. 
Table 1: Data on biological parameters of 4 populations of red palm weevil and $F_{1}$ and $F_{2}$ Generations of various crosses

\begin{tabular}{|c|c|c|c|c|c|c|c|c|}
\hline \multirow[t]{2}{*}{$\begin{array}{l}\text { Populations/ } \\
\text { Crosses \& F1 }\end{array}$} & \multicolumn{2}{|c|}{ Eggs } & \multicolumn{2}{|c|}{ Grubs } & \multicolumn{2}{|c|}{ Pupae } & \multirow[t]{2}{*}{$\begin{array}{c}\% \\
\text { Survival } \\
\text { of egg to } \\
\text { adult }\end{array}$} & \multirow[t]{2}{*}{$\begin{array}{c}\text { Sex ratic } \\
\text { Male to } \\
\text { Female }\end{array}$} \\
\hline & Observed & $\%$ Hatch & Observed & \% Survival & Observed & \% Survival & & \\
\hline Arsikare & 217 & 53 & 117 & 37 & 43 & 77 & 15.7 & 0.83 \\
\hline Chawl & 201 & 75 & 151 & 31 & 47 & 77 & 17.9 & 0.50 \\
\hline Mettupalayam & 117 & 66 & 77 & 35 & 27 & 89 & 20.5 & 0.85 \\
\hline Kayangulam & 336 & 63 & 711 & 36 & 75 & 64 & 14.3 & 1.52 \\
\hline \multicolumn{9}{|l|}{ Crosses $F_{1}$} \\
\hline KIm x Met & 282 & 63 & 177 & 14 & 25 & 84 & 7.5 & 1.10 \\
\hline KIm $\times$ Ars & 196 & 77 & 150 & 23 & 34 & 71 & 12.2 & 1.40 \\
\hline Ars $\times \mathrm{Klm}$ & 74 & 72 & 53 & 51 & 77 & 67 & 24.3 & 0.64 \\
\hline Chw x KIm & 167 & 73 & 122 & 39 & 47 & 66 & 18.6 & 0.62 \\
\hline $\mathrm{Klm} \times \mathrm{Chw}$ & 83 & 83 & 69 & 52 & 36 & 50 & 21.7 & 1.25 \\
\hline Ars $x$ Met & 269 & 54 & 145 & 16 & 23 & 78 & 6.7 & 0.64 \\
\hline Met x Ars & 139 & 62 & 85 & 13 & 11 & 82 & 6.5 & 0.80 \\
\hline Ars $\times$ Chw & 146 & 48 & 70 & 51 & 36 & 78 & 19.2 & 1.80 \\
\hline \multicolumn{9}{|l|}{$\mathrm{F}_{2}$} \\
\hline $\mathrm{KIm} \times \mathrm{Met}$ & 218 & 67 & 145 & 20 & 29 & 79 & 10.6 & 0.92 \\
\hline KIm $\times$ Ars & 446 & 59 & 261 & 2 & 66 & 82 & 12.1 & 1.45 \\
\hline Ars $\times$ Klm & 163 & 60 & 98 & 47 & 46 & 85 & 23.9 & 0.85 \\
\hline Chw x KIm & 259 & 67 & 174 & 55 & 95 & 79 & 28.9 & 0.92 \\
\hline $\mathrm{KIm} \times \mathrm{Chw}$ & 65 & 69 & 45 & 60 & 27 & 81 & 33.9 & 1.44 \\
\hline Ars $x$ Met & 300 & 61 & 182 & 21 & 38 & 79 & 10 & 0.87 \\
\hline Met $x$ Ars & 127 & 62 & 79 & 22 & 17 & 94 & 12.6 & 1.22 \\
\hline Ars $\times$ Chw & 258 & 66 & 169 & 54 & 91 & 70 & 13.2 & 1.00 \\
\hline
\end{tabular}


Table 2: Chisquare analysis of biological parameters of 4 populations and $F_{1}$ And $F_{2}$ of their crosses

\begin{tabular}{|c|c|c|c|c|c|}
\hline & \multicolumn{3}{|c|}{ Survival of } & \multirow[b]{2}{*}{$\begin{array}{l}\text { Adults } \\
\text { emerged }\end{array}$} & \multirow[b]{2}{*}{$\begin{array}{c}\text { No. of } \\
\text { Females }\end{array}$} \\
\hline & $\begin{array}{l}\text { Eggs } \\
\text { Hatched }\end{array}$ & Grubs & Pupae & & \\
\hline Arsikare & 117 & 43 & 33 & 33 & 15 \\
\hline Chawl & 151 & 47 & 36 & 36 & 12 \\
\hline Mettupalayam & 77 & 27 & 24 & 24 & 11 \\
\hline Kayangulam & 711 & 75 & 48 & 48 & 29 \\
\hline \multicolumn{6}{|l|}{ Crosses: $F_{1}$} \\
\hline $\mathrm{KIm} \times \mathrm{Met}$ & 177 & 25 & 21 & 21 & 11 \\
\hline $\mathrm{KIm} \times$ Ars & 150 & 34 & 24 & 24 & 14 \\
\hline Ars $\times \mathrm{KIm}$ & 53 & 27 & 18 & 18 & 7 \\
\hline Chw $\times$ KIm & 122 & 47 & 31 & 31 & 13 \\
\hline $\mathrm{KIm} \times \mathrm{Chw}$ & 69 & 36 & 18 & 18 & 10 \\
\hline Ars $\times$ Met & 145 & 23 & 18 & 18 & 17 \\
\hline Met $\times$ Ars & 85 & 11 & 9 & 9 & 4 \\
\hline Met $x$ Ars & 70 & 36 & 28 & 28 & 18 \\
\hline \multicolumn{6}{|l|}{$\mathrm{F}_{2}$} \\
\hline $\mathrm{KIm} \times \mathrm{Met}$ & 145 & 29 & 23 & 23 & 11 \\
\hline $\mathrm{KIm} \times$ Ars & 261 & 66 & 54 & 54 & 32 \\
\hline Ars $\times \mathrm{KIm}$ & 98 & 46 & 39 & 34 & 18 \\
\hline Chw $\times$ KIm & 174 & 95 & 75 & 75 & 36 \\
\hline $\mathrm{KIm} \times \mathrm{Chw}$ & 45 & 27 & 22 & 22 & 13 \\
\hline Ars $\times$ Met & 182 & 38 & 30 & 30 & 14 \\
\hline Met $\times$ Ars & 79 & 17 & 16 & 16 & 9 \\
\hline Ars $\times$ Chw & 169 & 91 & 64 & 34 & 32 \\
\hline \multicolumn{6}{|l|}{ Chisquare values for } \\
\hline $\begin{array}{l}\text { All population } \\
\text { Together }\end{array}$ & $94.27^{\star *}$ & $273.54^{\star *}$ & $35.1^{*}$ & $133.87^{* *}$ & 15.80 \\
\hline Parental population & $20.7^{*}$ & 1.4 & 7.2 & 3.1 & 6.20 \\
\hline$F_{1}$ generation & $63.41^{* *}$ & $99.88^{*}$ & 10.93 & 47.50 & 5.91 \\
\hline $\mathrm{F}_{2}$ generation & 9.97 & $120.83^{\star *}$ & 7.80 & $76.04^{\star *}$ & 3.21 \\
\hline $\mathrm{Klm}$ and its crosses & $42.04^{\star \star}$ & $133.81^{* *}$ & $25.49^{*}$ & 88.53 & 7.91 \\
\hline
\end{tabular}

Ars $=$ Arsikare $\quad$ Met $=$ Mettupalayam

Chw $=$ Chawl $\quad \mathrm{Klm}=$ Kayangulam 
Table 3: Differences in the larval and pupal period of 4 populations of red Palm weevil

\begin{tabular}{|c|l|c|c|}
\hline SI NO. & \multicolumn{1}{|c|}{ Populations } & $\begin{array}{c}\text { Mean larval } \\
\text { Period }\end{array}$ & $\begin{array}{c}\text { Mean pupal } \\
\text { period }\end{array}$ \\
\hline 1. & Arsikare & 55.8 & 14.8 \\
2. & Chawl & 48.6 & 19.3 \\
3. & Mettupalam & 48.4 & 14.4 \\
4. & Kayangulam & 51.0 & 17.0 \\
& Gen. Mean & 51.6 & 16.5 \\
& CV \% & 30.4 & 24.5 \\
& F ratio & 1.71 & $8.96^{* *}$ \\
& CD $(\mathrm{P}=0.01)$ & NS & 1.92 \\
\hline
\end{tabular}

** Significant at $\mathrm{P}=0.01$

Table 4: Differences in the larval and pupal period of $F_{1}$ and $F_{2}$ generation of The crosses of 4 populations

\begin{tabular}{|l|l|r|r|r|r|}
\hline \multirow{3}{*}{ SI NO. } & \multicolumn{2}{|c|}{ Crosses } & \multicolumn{2}{|c|}{$\mathrm{F}_{1}$ Populations } & \multicolumn{2}{c|}{$\mathrm{F}_{2}$ Populations } \\
\cline { 3 - 6 } & & $\begin{array}{c}\text { Mean larval } \\
\text { Period }\end{array}$ & $\begin{array}{c}\text { Mean pupal } \\
\text { Period }\end{array}$ & $\begin{array}{c}\text { Mean larval } \\
\text { Period }\end{array}$ & $\begin{array}{c}\text { Mean pupal } \\
\text { period }\end{array}$ \\
\hline 1 & Klm x Met & 51.4 & 21.0 & 56.7 & 11.4 \\
2 & Klm x Ars & 52.9 & 20.7 & 39.9 & 12.2 \\
3 & Ars x Klm & 42.5 & 16.7 & 57.8 & 16.8 \\
4 & Chw x Klm & 48.7 & 15.6 & 50.7 & 16.9 \\
5 & Klm x Chw & 42.3 & 17.9 & 61.6 & 15.5 \\
6 & Ars x Met & 56.5 & 21.2 & 59.2 & 18.5 \\
7 & Met x Ars & 59.2 & 19.4 & 59.2 & 21.1 \\
8 & Ars x Chw & 47.8 & 14.9 & 40.1 & 14.5 \\
& Gen Mean & 48.6 & 17.6 & 48.9 & 15.4 \\
& CV \% & 23.0 & 24.2 & 29.9 & 26.5 \\
& F ratio & $6.26^{* *}$ & $7.57 * *$ & $14.35^{* *}$ & $14.97 * *$ \\
& Critical ifference & 5.96 & 2.56 & 6.31 & 1.94 \\
\hline
\end{tabular}

** significant at $\mathrm{P}=0.01$ 
Fig 1. Map of India showing areas from where populations collected

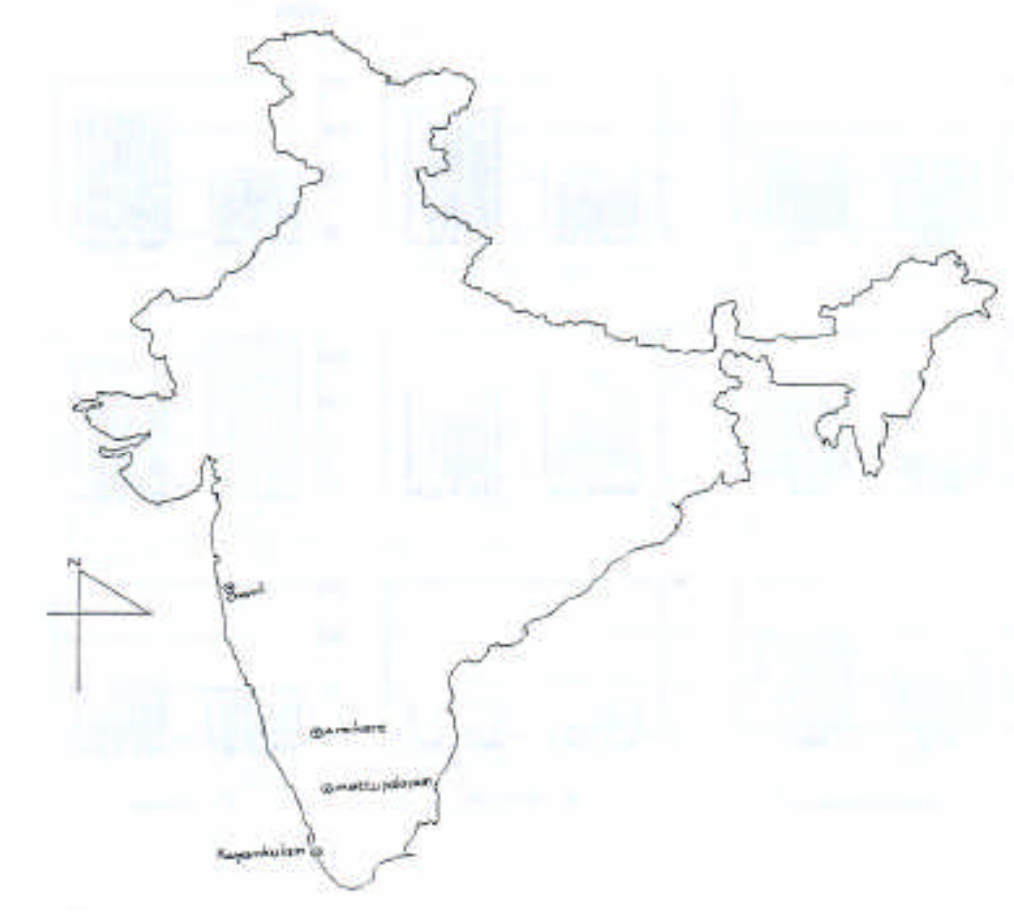

Fig 2. Survival rate in four populations of Red palm weevil, $F_{1}$ and $F_{2}$ of their crosses and reciprocal crosses
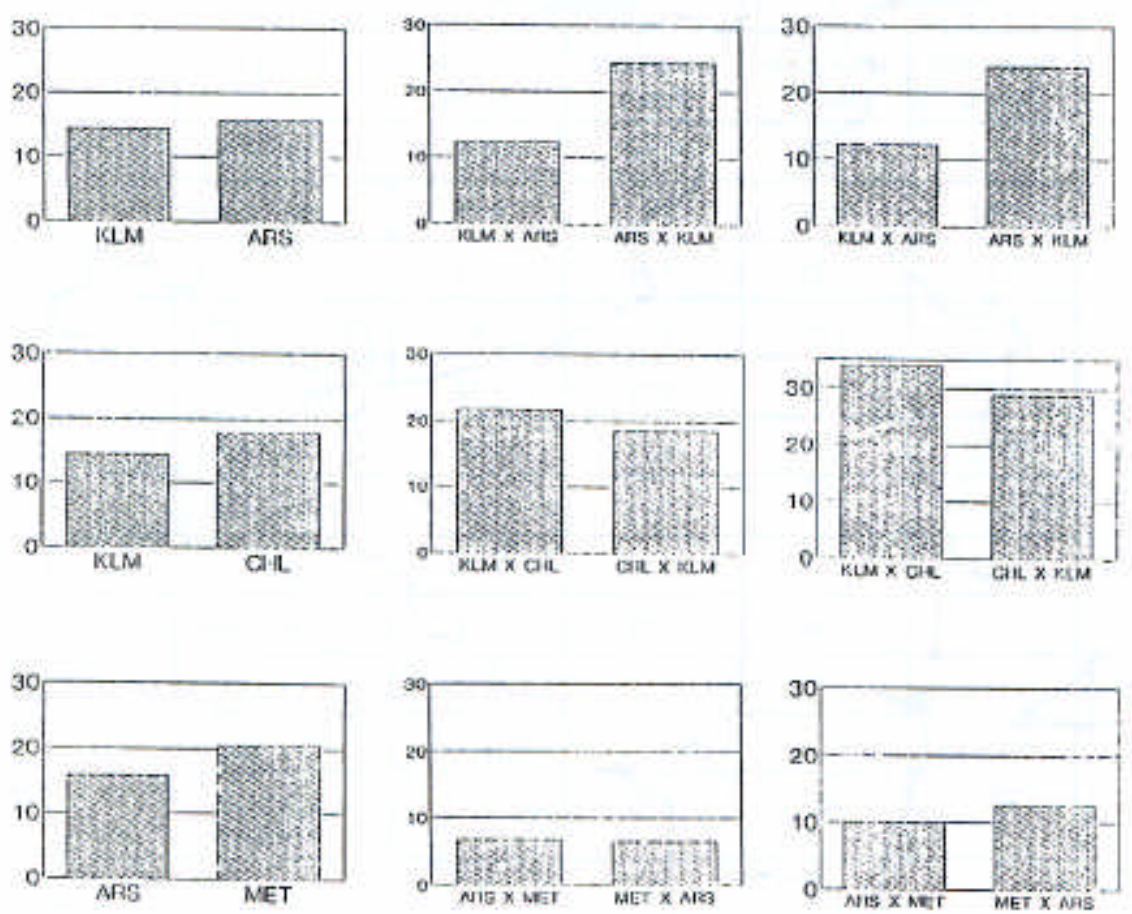

Pareat populavion

$F_{1}$ - Civesess

$\mathrm{F}_{2}-$ - Crossas 
Fig 3. Variations in sex ratio among four populations of Red palm weevil and $F_{1}$ and $F_{2}$ of their crosses and reciprocal crosses
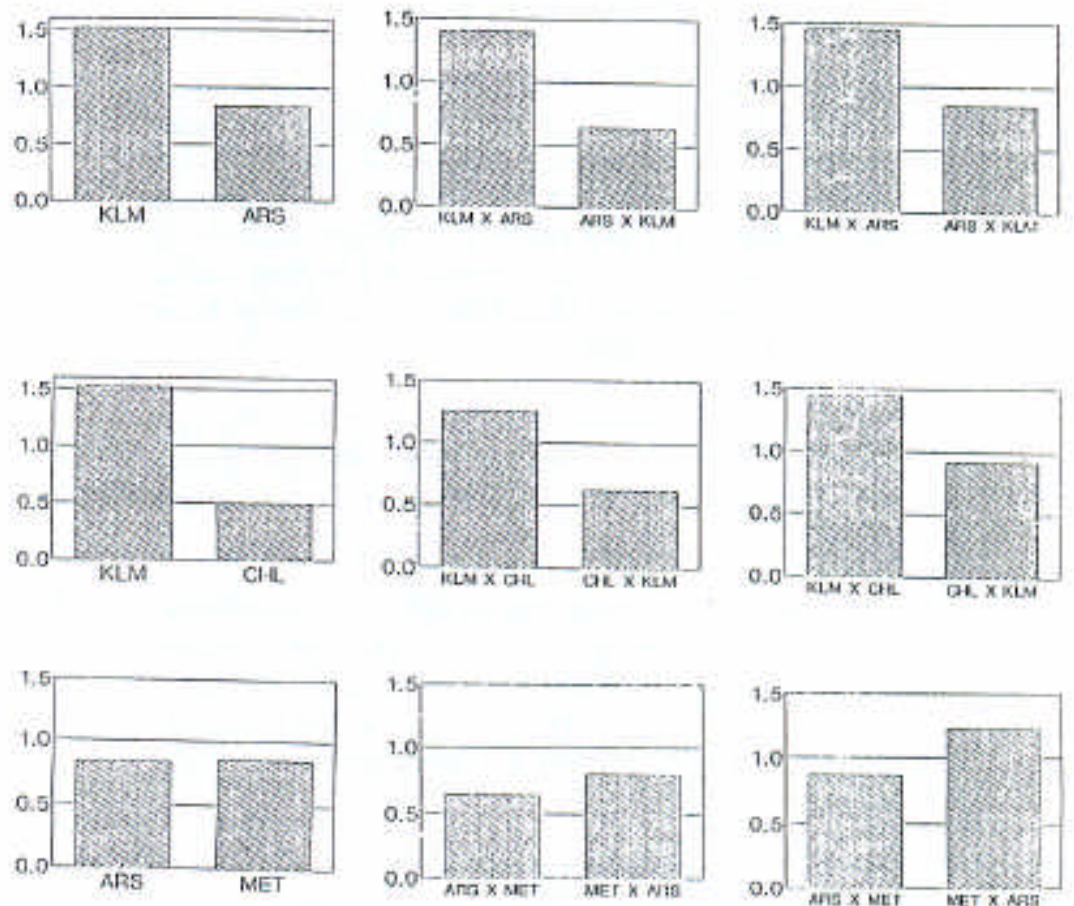

Parent populatien

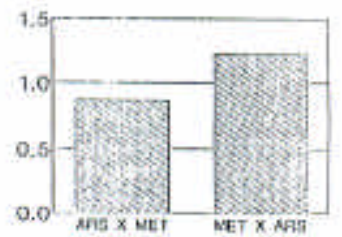

$F_{2}$ 